\title{
A note on assessing Hidden Hunger in African Countries
}

\author{
Lincoln J Fry* \\ Academic Member, Sociology Research Unit, Greece
}

*Corresponding author: Lincoln J Fry, Academic Member, Sociology Research Unit, Athens Institute for Education and Research, (ATINER) Athens, 974 SW. General Patton terrace, Port St Lucie, Florida, 34953

\begin{tabular}{|c|c|}
\hline ARTICLE INFO & ABSTRACT \\
\hline Received: 幽 February 21, 2019 & Citation: Lincoln J Fry. A note on assessing Hidden Hunger in African Countries. Biomed J Sci \\
\hline Published: March 12, 2019 & \& Tech Res 15(5)-2019. BJSTR. MS.ID.002760. \\
\hline
\end{tabular}

\section{Opinion}

Among the various meanings of hunger, one refers to the want or scarcity of food in a country, and it is in that sense that this note addresses hunger. This paper presents findings from an ongoing research project as well as the data included in a merged file which contains the country level surveys of 36 African countries. The purpose is to demonstrate that existing survey research provides a means to assess the scope of hunger in these African countries. Because this note reports on a study that utilizes a self-report measure to assess hunger, the results may be seen to reflect a country's total hunger level. That is because persons included in each country's sample included respondents who might have been enumerated in formal hunger measures as well as unreported persons that reflect what is known as hidden hunger in their respective countries.

\section{Hunger}

There are formal measures which include those who demonstrate clear cut hunger; in the latest UN Food and Agriculture Organization Report [1], the estimate was that 925 million people were hungry worldwide, and that 239 million people in sub- Saharan Africa were hungry or undernourished. This made Africa the continent with the second largest number of hungry people following Asia, and the pacific with 578 million. Due to the difference in population sizes, Sub-Saharan Africa actually had the largest proportion of hungry/undernourished people, estimated at 30 percent of the population compared to 16 percent in Asia and the Pacific. What is known as hidden hunger is major concern and there are an estimated two billion persons that are affected by a chronic deficiency of essential vitamins and minerals. Among this

population the signs of malnutrition and hunger are less visible, but it has negative and long-term consequences, often for long term health, productivity and cognitive development (Muthayya).

\section{Hunger in Sub-Saharan Africa}

As Clover [2] has suggested, despite the fact that the right to food is one of the most consistently acclaimed assertions in international human rights law, no other human right has been so frequently and spectacularly violated. Her discussion of food insecurity in SubSaharan Africa leads to the conclusion that hunger is a multi-faceted issue in Africa, and that just growing more food will not eradicate the problem. Agriculture is important and Clover points out that Africa has gone from being a key agricultural commodity exporter into being a net importer; the African continent now receives the most food aid. Perhaps the most important point Clover made was to suggest hunger will not be eradicated by just throwing money at the problem.

\section{Measuring hunger}

As Godecke et al. [3] have indicated, measuring hunger remains problematic. This does not mean that hunger has been ignored. There has been an effort in the research community to develop hidden hunger measures, indices and maps. (Muthayya) Both Godecke and Muthayya point to the lack of national probability samples as the primary roadblock. These indices and mapping efforts have been productive and are useful here because they highlight the role of several important factors that are addressed on this paper. One is the fact that African farmers may be hungrier than the rest of the population, and also that gender may be a factor, with 
women hungrier than men. The objective of this note is to identify policy related factors that might help alleviate hunger problems at the country level.

\section{The Data}

This research's Data Source is the Afrobarometer project, which started with 12 countries in Round 1 and by 2014 when Round 6 was completed included 36 African countries. The project uses a standardized questionnaire with new questions or country specific questions added by round. The individual country is the unit of analysis and sampling goal is to create national probability samples which represent cross sections of adult citizens, 18 years and older for each country. Sampling sizes are set at either 1,200 or 2,400 respondents, depending upon the country's population size. The sampling procedures used in all of the Afrobarometer surveys are explained in detail in Bratton et al. [4].

\section{Measures}

The study's questionnaire included what is called The Lived Poverty Index used in the Afrobarometer studies which was adopted from Mattes. One of the five questions in the Index asked, "over the past year, how often, if ever, have you or anyone in your family gone without enough food to eat". Fixed responses to this question were: never, just once or twice, several times, many times, always. These responses were coded as follows: Never $=\mathrm{I}$, just once or twice $=2$ and many times and always $=3$. This is the only measure included in the Afrobarometer survey that will be used in this note. Table 1 shows the countries that have been identified as the world's hungriest nations, lists Africa's hungriest countries and then shows the percentages of persons in African countries who reported being hungry many times or always. These numbers were derived through a breakdown of Round 6 of Afrobarometer survey by country and earlier epapers which have presented country level results include Fry et al. [5-7].

\section{Discussion}

Table 1 does make it clear that Africa is the major source of the world's hunger. The first 9 countries on the world's hungriest list are all African countries, with a single Asian country completing the top 10. The numbers assigned to each country are taken from the Global Hunger Index [7-9], which is designed to comprehensively measure and track hunger at the global, regional and country levels. Perhaps what is most surprising is the lack of correspondence between the countries based on the GHI and the Afro barometer samples. While it is true that the Afrobarometer file contains 36 countries of Africa's 54 countries, the fact remains that some of those identified as Africa's hungriest countries are included in the Afrobarometer file and did not appear on the list of that files hungriest African countries. This discrepancy will provide the basis for the next paper in the series, namely in the quest to identify the answer the question as to who Africa's hungriest countries.

Table 1: Countries Identified as Africa's and the World's Hungriest countries.

\begin{tabular}{|c|c|c|c|}
\hline Rank & World & Africa & Afrobarometer \\
\hline 1 & Central African Republic & Burundi 35.6 & Malawi (30) \\
\hline 2 & Chad & Eritrea 33. & Niger (27) \\
\hline 3 & Sierra Leon & Comoros 29.5 & Lesotho (25) \\
\hline 4 & Madagascar & Sudan 26.0 & Liberia (24) \\
\hline 5 & Zambia & Chad 24.9 & Burundi (23) \\
\hline 6 & Yemen & Ethiopia 24.4 & Gabon (22) \\
\hline 7 & Sudan & Zambia 23.2 & Guinea (21) \\
\hline 8 & Liberia & Sierra Leone 22.5 & Togo (20) \\
\hline 9 & Niger & Madagascar 21.9 & Sierra Leone (20) \\
\hline 10 & Timor-Leste & Central African Republic 21.5 & Mozambique (19) \\
\hline
\end{tabular}

\section{References}

1. (2015) UN Food and Agriculture Organization Report, The State of Food and Agriculture.

2. Clover J (2003) Food security in sub-Saharan Africa. African security review 12(1): 5-15.

3. Godecke T, Stein A, Qaim M (2018) The Global Burden of Chronic and Hidden hunger: Trends and Determinants. Global Food Security 17: 2129.

4. Bratton M, Mattes R, Gyimah Mattes E (2005) Public opinion, democracy, and market reform in Africa. Cambridge University Press, UK.
5. Fry L (2017) Is Hunger Destined to be Perpetual in Burundi? Food Science and Nutrition Studies 1(1): 201.

6. Lincoln J Fry (2018a) Hidden hunger in Benin: the scope and prospectus. Journal of Food Science and Nutrition Studies 1(1): 3-8.

7. (2018) The Scope of Hidden Hunger in Zarnbia: Food Science and Nutrition Technology ISSN: Vol3 No3 Global Hunger Index.

8. (2015) Facts: Top 10 Hungriest African Countries.

9. (2019) The World's Ten Hungriest Countries. 
ISSN: 2574-1241

DOI: 10.26717/BJSTR.2019.15.002760

Lincoln J Fry. Biomed J Sci \& Tech Res

(C) This work is licensed under Creative

Submission Link: https://biomedres.us/submit-manuscript.php

$\begin{array}{ll}\text { BIOMEDICAL } & \text { Assets of Publishing with us } \\ \text { RESEARCHES } & \text { - Global archiving of articles } \\ & \text { - Immediate, unrestricted online access } \\ & \text { - Rigorous Peer Review Process } \\ \end{array}$

